\title{
Genetic Disorders of Neonatal Respiratory Function
}

\author{
F. SESSIONS COLE, AARON HAMVAS, AND LAWRENCE M. NOGEE \\ Edward Mallinckrodt Department of Pediatrics, Washington University School of Medicine, and St. Louis \\ Children's Hospital, St. Louis, Missouri 63110, U.S.A.[F.S.C., A.H.], and Division of Neonatology, \\ Department of Pediatrics, Johns Hopkins University School of Medicine, Baltimore, Maryland 21287, \\ U.S.A. [L.M.N.]
}

\begin{abstract}
ABST
Genetic risk for respiratory distress in infancy has been
recognized with increasing frequency in neonatal intensive care
units. Reports of family clusters of affected infants and of ethnic-
and gender-based respiratory phenotypes point to the contribu-
tion of inheritance. Similarly, different outcomes among gesta-
tionally matched infants with comparable exposures to oxygen,
mechanical ventilation, or nutritional deficiency also suggest a
genetic risk for respiratory distress. Examples of inherited defi-
ciency of surfactant protein B in both humans and genetically
engineered murine lineages illustrate the importance of identify-
ing markers of genetic risk. In contrast to developmental, inflam-
\end{abstract}
matory, or nutritional causes of respiratory distress that may resolve as infants mature, genetic causes result in both acute and chronic (and potentially irreversible) respiratory failure. The availability of clinically useful genetic markers of risk for respiratory distress in infancy will permit development of rational strategies for treatment of genetic lung disorders of infancy and more accurate counseling of families whose infants are at genetic risk for development of respiratory distress at birth or during early childhood. We review examples of genetic variations known to be associated with or cause respiratory distress in infancy. (Pediatr Res 50: 157-162, 2001)
Respiratory distress syndrome in newborn infants is the most frequent respiratory cause of death and morbidity in children $<1 \mathrm{y}$ of age in the United States (1). It is also predictive of risk for chronic pulmonary diseases in childhood (2-5). Survivors of respiratory distress syndrome with asthma and bronchopulmonary dysplasia consume 20 times more annualized dollars than unaffected children $(\$ 19,104$ versus $\$ 955)$ and $5.9 \%$ of all dollars spent on children from 0 to $18 \mathrm{y}$ of age (6). Since the original description of surfactant deficiency, respiratory distress syndrome has most commonly been attributed to developmental immaturity of pulmonary surfactant production (7, 8). Pulmonary surfactant is a mixture of phospholipids and proteins synthesized, packaged, and secreted by type II pneumocytes that line the distal airways. This mixture forms a monolayer at the air-liquid interface that lowers surface tension at end expiration of the respiratory cycle and thereby prevents atelectasis and ventilation-perfusion mismatch. Availability of

Received December 29, 2000; accepted February 8, 2001.

Correspondence and reprint requests: F. Sessions Cole, M.D., Division of Newborn Medicine, Department of Pediatrics, St. Louis Children's Hospital, One Children's Place, St. Louis, MO 63110, U.S.A.; e-mail: cole@kids.wustl.edu

Supported in part by grants from the National Heart, Lung, and Blood Institute RO1 HL/HD 54187 (F.S.C.), HL 54703 (L.M.N.), and the Eudowood Foundation (L.M.N.). surfactant replacement therapy has been associated with a decline during the last $10 \mathrm{y}$ in the mortality of respiratory distress syndrome among premature infants $(1,9-11)$.

Despite improvement in neonatal survival, long-term respiratory morbidity and mortality have persisted in a significant fraction (5-25\%) of affected infants (12-15). Pulmonary morbidity has been attributed to oxygen toxicity, barotrauma, developmental immaturity, and nutritional deficiencies. However, significant differences in pulmonary outcomes among developmentally similar infants with comparable exposures to oxygen, mechanical ventilation, and nutritional deficiency suggest that genetic factors contribute to pulmonary outcome. Genetic risk for respiratory distress in infancy has also been suggested by reports of family clusters of affected infants, by studies of different ethnic groups and sex, by characterization of infants with inherited deficiency of surfactant protein B, and by targeted gene ablation in murine lineages (16-28). In contrast to nongenetic causes of respiratory distress that may resolve as infants mature, genetic causes result in both acute and chronic (and potentially irreversible) respiratory failure. In contrast to cystic fibrosis or $\alpha_{1}$-antitrypsin deficiency that leads to chronic respiratory phenotypes in childhood owing to gradual destruction of normal lung parenchyma, genetic disorders 
that present in the neonatal period acutely disrupt alveolar function. The availability of clinically useful genetic markers of risk for respiratory distress in infancy would permit development of anticipatory and therapeutic strategies to reduce their significant medical and economic costs. Genetic variation in human surfactant protein genes $\mathrm{A}, \mathrm{B}$, and $\mathrm{C}$, and in other extrapulmonary genes (granulocyte-macrophage colonystimulating factor and its receptor) has provided the first examples of such genetic tools. Two mechanistically distinct groups of genetic markers have been identified: those statistically linked to risk of respiratory distress (e.g. surfactant protein A) and those that result in loss of surfactant function (e.g. surfactant protein B).

\section{SURFACTANT PROTEIN A}

The human surfactant protein A locus consists of two functional genes (SP-A1 and SP-A2) and a pseudogene $(19,29)$. Each of the two functional genes contains four coding exons and directs the synthesis of a distinct primary translation product (30). Of the $>15$ alleles of the SP-A2 gene identified to date, one $\left(1 \mathrm{~A}^{0}\right)$ has recently been observed in significantly higher frequency among unrelated, premature white infants $>28$ wk gestation with respiratory distress (31). This allele has also been associated with low levels of surfactant protein A transcript in human lung tissue of unrelated individuals (32). In a recent study of 88 infants with respiratory distress syndrome and 88 control subjects from the genetically homogeneous Finnish population, both protective and susceptibility effects were observed with different surfactant protein A alleles (33). In murine lineages with targeted ablation of the surfactant protein A gene, prematurely delivered pups lack tubular myelin but do not develop respiratory distress (34-36).

In addition to its role in surfactant function, surfactant protein $\mathrm{A}$ is a member of the collectin subgroup of mammalian C-type lectins that also includes surfactant protein D, mannosebinding protein, and conglutinin $(37,38)$. The role of surfactant protein $\mathrm{A}$ in host defense has been suggested by increased susceptibility to viral and bacterial infections observed in murine lineages with genetically ablated surfactant protein A production (39-41). Murine and human studies thus suggest that alleles associated with low concentrations of surfactant protein A may increase the genetic risk of respiratory distress and infection (19). However, to date, no human infants who lack surfactant protein A have been identified, and the human respiratory phenotype associated with the SP-A2 $1 \mathrm{~A}^{0}$ allele has been demonstrated to be variable (19). The complexity of the genetic contribution of surfactant protein A to respiratory distress in infancy and to risk of infection makes surfactant protein A polymorphisms promising but not currently useful for estimation of individual risk of having an affected infant.

\section{SURFACTANT PROTEIN B}

In contrast to surfactant protein $\mathrm{A}$, genetic disruption of surfactant protein B expression causes an unambiguous neonatal respiratory phenotype in both human infants and mice. The surfactant protein B gene has been sequenced and its regulatory regions characterized (Fig. 1) (42). The gene spans approximately 10 kilobases $(\mathrm{kb})$ and has 11 exons. Exons 1 through 11 encode a $2-\mathrm{kb}$ transcript that directs the synthesis of a 381-amino acid preproprotein that is subsequently glycosylated and proteolytically processed before incorporation into pulmonary surfactant $(43,44)$. The mature $8-\mathrm{kD}$ protein is encoded in exons 6 and 7. Identified mutations and single nucleotide polymorphisms occur throughout the surfactant protein B gene, as indicated in Figure 1.

Surfactant protein B deficiency was the first reported genetic cause of lethal respiratory distress syndrome in infants (45). Affected infants in the initial kindred were homozygous for a mutation that involved a 1-bp deletion and 3-bp insertion at codon 121 in exon 4 of the surfactant protein B gene (121ins2). This mutation results in a frameshift and premature translation stop signal at codon 214 that accounts for the lack of protein by immunohistochemical staining and in tracheal effluent (46). Nuclear run-on assays performed with nuclei from lungs of affected infants suggest that the mutated gene is transcribed normally, but the transcript is unstable (47). The mutation creates a new $S f u \mathrm{I}$ restriction site that facilitates its rapid detection. In addition, pro-surfactant protein $\mathrm{C}$ peptides with aberrant mobility on SDS-PAGE and with increased abundance by immunohistochemical staining and by Western blot analysis have been observed in affected infants and in mice with genetically engineered abrogation of surfactant protein $\mathrm{B}$ synthesis (45-48). Abnormal processing of pro-surfactant protein $\mathrm{C}$ most likely accounts for its altered mobility $(47,48)$. The mechanism for enhanced accumulation is unknown.

The clinical phenotype for infants homozygous for this mutation is consistent: full-term infants develop respiratory distress within the first $12-24 \mathrm{~h}$ of life and, without lung transplantation, expire within the first $1-6$ mo of life $(49,50)$. Surfactant replacement therapy, corticosteroid treatment, and mechanical ventilatory support fail to reverse this outcome (51). The only available treatment for affected infants is lung transplantation (52). These family studies suggested that a single-gene, loss-of-function mutation results in irreversible respiratory distress syndrome in infancy. To make this genetic marker useful for individual risk assessment, animal, human, and population-based studies are necessary to correlate biochemical and clinical phenotype with genotype.

Genetic and biochemical studies of compound heterozygote infants, heterozygote adults, and mice heterozygous for targeted disruption of the surfactant protein B gene suggest that approximately $50 \%$ of normal surfactant protein B synthesis

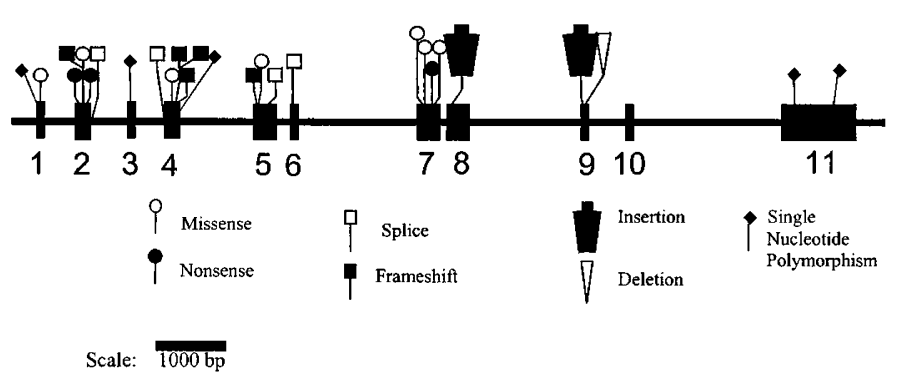

Figure 1. Molecular structure and genetic variation of the surfactant protein B gene. 
may be sufficient for normal pulmonary function at birth (17, $18,53-56)$. The minimum surfactant protein $\mathrm{B}$ production required for normal surfactant metabolism and lung function in humans and mice is unknown. An infant who produced only $8-10 \%$ of the normal amount of surfactant protein B because of different loss-of-function mutations on each chromosome experienced acute and chronic respiratory distress after birth and died of respiratory causes at $9.5 \mathrm{mo}$ of age (53). Two other unrelated children homozygous for a mutation in exon 5 $(479 \mathrm{G} \rightarrow \mathrm{T})$ that creates an alternative donor splice site had reduced surfactant protein $\mathrm{B}$ and chronic respiratory distress: one required lung transplantation, and the other has chronic respiratory insufficiency (57). In mice heterozygous for targeted disruption of surfactant protein B production, reduced synthesis led to air trapping and chronic lung damage when exposed to hyperoxia (58). These observations suggest that acute and chronic respiratory distress syndrome may result from genetic variation in the human surfactant protein B gene.

To determine whether microsatellite markers would be useful in prediction of genetic risk of respiratory distress, population-based studies to evaluate genotype-phenotype correlation were necessary (Table 1). Among the 1260 individuals examined, polymorphic tandem-repeat sequences in intron 4 and intergenic microsatellite markers have been linked to risk of respiratory distress $(31,59-63)$. However, control populations of insufficient size have limited the ability to use these markers in clinical practice or parental counseling.

To determine the frequency of the 121ins 2 mutation, we used clinical and molecular ascertainment in two large, population-based cohorts (64). We found one 121ins2 allele per 3300 individuals from a New York cohort by molecular ascertainment and one 121 ins 2 allele per 1000 individuals from a Missouri cohort by clinical ascertainment. The rare population frequency of the 121 ins 2 mutation, the consistent phenotype exhibited by infants with a homozygous genotype, and the absence of biologic redundancy for surfactant protein B function permit unambiguous counseling of parents of fetuses or infants homozygous for this mutation about disease progression, prognosis, and treatment options. In a cohort of infants with hereditary surfactant protein B deficiency, the 121ins2 mutation was the most frequently identified mutation and was found on approximately $60 \%$ of chromosomes (65). Other investigators and we have identified 27 mutations or singlenucleotide polymorphisms in the surfactant protein B gene (Fig. 1) (59-65). Other loss-of-function mutations appear to be family specific and result in respiratory distress, but sometimes with more gradually progressive respiratory failure. These findings permit prediction of acute or chronic respiratory distress in infants who carry any loss-of-function mutations on both alleles.

\section{SURFACTANT PROTEIN C}

Surfactant protein $\mathrm{C}$ is a hydrophobic protein that is synthesized from a precursor of either 191 or 197 amino acids (depending on differential splicing of the primary transcript) and proteolytically cleaved (66-68). Interestingly, prosurfactant protein $\mathrm{C}$ does not contain an $\mathrm{N}$-terminal signal peptide but does have hydrophobic domains (66). Mature surfactant protein $C$ contains 35 amino acid residues and can be found in both airways and in lamellar bodies. A murine lineage with targeted ablation of the surfactant protein $\mathrm{C}$ gene has been reported to exhibit no respiratory distress at birth (69). In addition, human respiratory disease in the neonatal period caused by loss-of-function mutations in the surfactant protein $\mathrm{C}$ gene has not been identified. However, a recent report describes a family with a splice site mutation at the first base of intron 4 of the surfactant protein $\mathrm{C}$ gene, development of chronic interstitial lung disease in affected family members, and an autosomal dominant inheritance pattern (70). This report and the results of the surfactant protein $\mathrm{C}$ knockout lineage suggest that genetic variation in the surfactant protein $\mathrm{C}$ gene results in chronic respiratory disease rather than acute respiratory distress syndrome of infancy.

\section{SURFACTANT PROTEIN D}

Surfactant protein D is a member of the collectin family and is expressed in extrapulmonary tissues. Its functions include carbohydrate-domain recognition on the surface of pathogens $(71,72)$. Murine lineages with targeted ablation of the surfac-

Table 1. Human surfactant protein B gene microsatellite markers

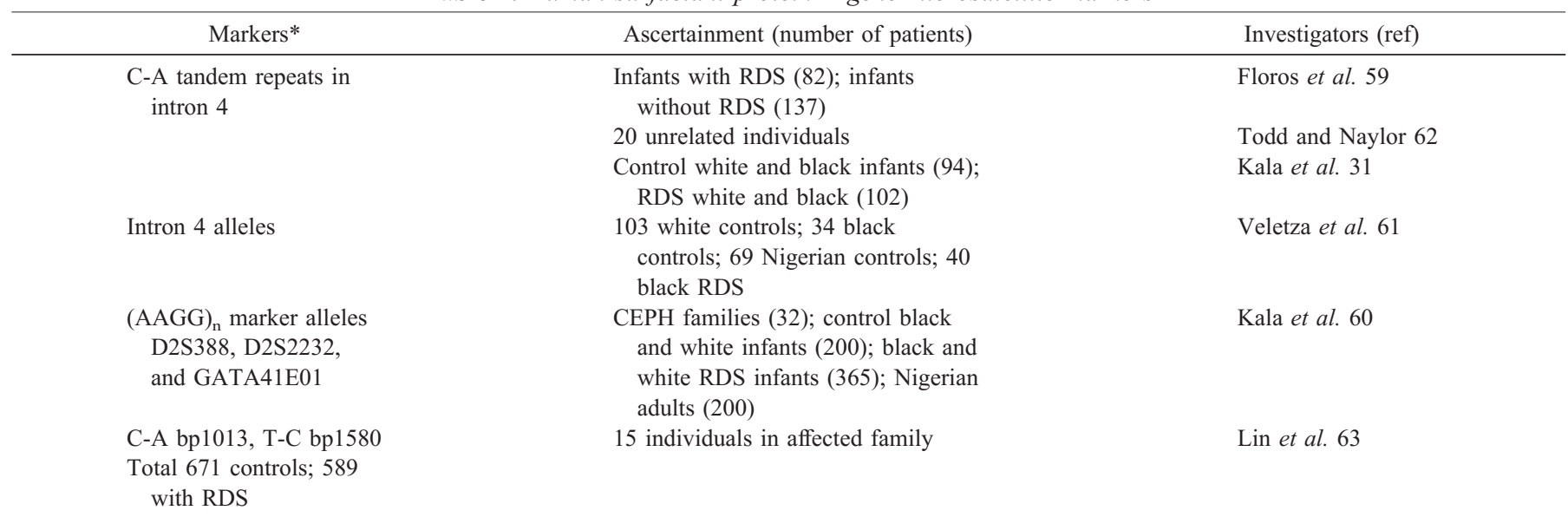

Abbreviations used: ref, reference; CEPH, Centre d'Etude du Polymorphisme Humain; RDS, respiratory distress syndrome.

* Genomic numbering. 
tant protein $\mathrm{D}$ gene have no respiratory abnormalities at the time of birth (73). Progressive extracellular accumulation of surfactant lipids and of surfactant proteins A and B, activation of alveolar macrophages and peribronchiolar-perivascular inflammation, and development of emphysema were observed during the first $8 \mathrm{wk}$ of age $(73,74)$. No human infant or older individual with respiratory distress and mutation in the surfactant protein $\mathrm{D}$ gene has been identified. Although differences between genomic and cDNA sequences for surfactant protein D have been observed (75), human genetic variation in this gene has not been studied in detail. Two biallelic polymorphisms of the surfactant protein $\mathrm{D}$ gene have been reported (76). Because of the role of the amino terminal region in multimerization to dodecamers critical for many functions of surfactant protein D, amino acid substitution in this region may have greater impact on function. However, the contributions of sequence variants in the surfactant protein D gene to respiratory distress syndrome in infancy await further study.

\section{EXTRAPULMONARY GENE PRODUCTS}

Targeted disruption of the genes that encode either granulocyte-macrophage colony-stimulating factor or its receptor (GM-CSF/IL-3/IL-5 receptor common $\beta$-chain) in mice resulted in pulmonary alveolar proteinosis (77). These observations demonstrated the important role of extrapulmonary gene products in surfactant production and function. Subsequently, patients with acquired alveolar proteinosis have been identified who either fail to express the GM-CSF/IL-3/IL-5 receptor common $\beta$-chain or have neutralizing antibody of $\mathrm{IgG}$ isotype against granulocyte-macrophage colony-stimulating factor in bronchoalveolar lavage $(78-80)$. Success in restoring surfactant homeostasis in mice with disrupted expression of granulocyte-macrophage colony-stimulating factor or its receptor by aerosolization of granulocyte-macrophage colony-stimulating factor or by bone marrow transplantation of wild-type bone marrow cells suggests novel strategies for treatment of respiratory distress syndrome in infancy $(81,82)$. However, to date, studies of infants and informative kindreds, genotypephenotype studies, and population studies necessary to permit use of these genetic markers for counseling of individual families have not been performed.

\section{SUMMARY}

Antenatal or postnatal identification of infants homozygous for the 12 lins 2 mutation in the surfactant protein B gene permits unambiguous counseling concerning lethal prognosis of affected infants and treatment options. Identification of infants with loss-of-function mutations in this gene permits reliable prediction of development of acute or chronic respiratory distress. A family history of neonatal or infant death caused by unexplained respiratory distress should prompt consideration of genetic testing for these mutations. Additional population-based analyses of genotype-phenotype correlation, including both respiratory distress in the neonatal period and long-term respiratory morbidity, are required to quantify the contribution of mutations in surfactant protein genes and extrapulmonary genes to the frequency of respiratory distress syndrome and subsequent pulmonary disease. For example, although the frequency of the 121 ins 2 mutation in the general population is rare, the frequencies of mutations that cause reduced surfactant protein B production have not been assessed. Molecular amplification and high throughput analysis methods for identifying genetic variation in DNA samples from large populations make possible such frequency estimation without the need for sequencing DNA of each individual $(83,84)$. Population-based studies are critical to avoid exaggeration or underestimation of the contribution of specific mutations or polymorphisms to respiratory distress syndrome in infants owing to ethnic stratification, environmental selection, or genotype-phenotype heterogeneity (85-87). Ongoing state programs for detection of inherited diseases provide access to DNA samples that may be linked anonymously to birth and infant death certificate databases that contain clinical information or sufficient identifiers to evaluate respiratory phenotype $(88,89)$. Once identified, these mutations will permit development of more rational strategies for treatment of genetic lung disorders of infancy and more accurate counseling for families whose infants are at genetic risk for development of respiratory distress at birth or during early childhood.

Acknowledgments. The authors thank Erika Crouch, M.D., Ph.D., Joanna Floros, Ph.D., and Harvey R. Colten, M.D., for helpful discussions, and Dawn Rouse for secretarial assistance.

\section{REFERENCES}

1. Guyer B, Martin JA, Hoyert DL, Martin JA, Ventura SJ, MacDorman MF, Strobino DM 1999 Annual summary of vital statistics, 1998. Pediatrics 104:1229-1246

2. Bertrand JM, Riley SP, Popkin J, Coates AL 1985 The long-term sequelae of prematurity: the role of familial airway hyperreactivity and the respiratory distress syndrome. N Engl J Med 312:742-745

3. Nickerson BG, Taussig LM 1980 Family history of asthma in infants with bronchopulmonary dysplasia. Pediatrics 65:1140-1144

4. Demissie K, Marcella S, Breckenridge MB, Rhoads GG 1998 Maternal asthma and transient tachypnea of the newborn. Pediatrics 102:84-90

5. Nickerson B 1995 Bronchopulmonary dysplasia and family history of asthma. [Letter] Pediatr Pulmonol 20:276

6. Ireys HT, Anderson GF, Shaffer TJ, Neff JM 1997 Expenditures for care of children with chronic illnesses enrolled in the Washington State Medicaid program, fiscal year 1993. Pediatrics 100:197-204

7. Avery ME, Mead J 1959 Surface properties in relation to atelectasis and hyaline membrane disease. Am J Dis Child 97:517-523

8. Whitsett JA, Stahlman MT 1998 Impact of advances in physiology, biochemistry, and molecular biology on pulmonary disease in neonates. Am J Respir Crit Care Med 157(suppl):S67-S71

9. Jobe AH 1993 Pulmonary surfactant therapy. N Engl J Med 328:861-868

10. Schwartz RM, Luby AM, Scanlon JW, Kellogg RJ 1994 Effect of surfactant on morbidity, mortality and resource use in newborn infants weighing 500 to $1500 \mathrm{~g}$. N Engl J Med 330:1476-1480

11. Vohr BR, Wright LL, Dusick AM, Mele L, Verter J, Steichen JJ, Simon NP, Wilson DC, Broyles S, Bauer CR, Delaney-Black V, Yolton KA, Fleisher BE, Papile L-A, Kaplan MD 2000 Neurodevelopmental and functional outcomes of extremely low birth weight infants in the National Institute of Child Health and Human Development Neonatal Research Network, 1993-1994. Pediatrics 105:1216-1226

12. Chye JK, Gray PH 1995 Rehospitalization and growth of infants with bronchopulmonary dysplasia: a matched control study. J Paediatr Child Health 31:105-111

13. Fenton AC, Mason E, Clarke M, Field DJ 1996 Chronic lung disease following neonatal ventilation. II. Changing incidence in a geographically defined population. Pediatr Pulmonol 21:24-27

14. McColley SA 1998 Bronchopulmonary dysplasia: impact of surfactant replacement therapy. Pediatr Clin North Am 45:573-586

15. Parker RA, Lindstrom DP, Cotton RB 1996 Evidence from twin study implies possible genetic susceptibility to bronchopulmonary dysplasia. Semin Perinatol 20:206-209

16. Hamvas A, Wise PH, Yang RK, Wampler NS, Noguchi A, Maurer MM, Walentik CA, Schramm WF, Cole FS 1996 The influence of the wider use of surfactant therapy on neonatal mortality among blacks and whites. N Engl J Med 334:1635-1640

17. Clark JC, Wert SE, Bachurski CJ, Stahlman MT, Stripp BR, Weaver TE, Whitsett JA 1995 Targeted disruption of the surfactant protein B gene disrupts surfactant ho- 
meostasis, causing respiratory failure in newborn mice. Proc Natl Acad Sci USA 92:7794-7798

18. Clark JC, Weaver TE, Iwamoto HS, Ikegami M, Jobe AH, Hull WM, Whitsett JA 1997 Decreased lung compliance and air trapping in heterozygous SP-B-deficient mice. Am J Respir Cell Mol Biol 16:46-52

19. Floros J, Kala P 1998 Surfactant proteins: molecular genetics of neonatal pulmonary diseases. Annu Rev Physiol 60:365-384

20. Fujikura T, Froehlich LA 1966 The influence of race and other factors on pulmonary hyaline membranes. Am J Obstet Gynecol 95:572-578

21. Hulsey TC, Alexander GR, Robillard PY, Annibale DJ, Keenan A 1993 Hyaline membrane disease: the role of ethnicity and maternal risk characteristics. Am J Obste Gynecol 168:572-576

22. Miller HC, Futrakul P 1968 Birth weight, gestational age, and sex as determining factors in the incidence of respiratory distress syndrome of prematurely born infants J Pediatr 72:628-635

23. Perelman RH, Palta M, Kirby R, Farrell PM 1986 Discordance between male and female deaths due to the respiratory distress syndrome. Pediatrics 78:238-244

24. Richardson DC, Torday JS 1994 Racial differences in predictive value of the lecithin/sphingomyelin ratio. Am J Obstet Gynecol 5:1273-1274

25. Robillard PY, Hulsey TC, Alexander GR, Sergent MP, De Caunes F, Papiernik E 1994 Hyaline membrane disease in black newborns: does fetal lung maturation occur earlier? Eur J Obstet Gynecol Reprod Biol 55:157-161

26. Nagourney BA, Kramer MS, Klebanoff MA, Usher RH 1996 Recurrent respiratory distress syndrome in successive preterm pregnancies. J Pediatr 129:591-596

27. Farrell PM, Gilbert EF, Zimmerman JJ, Warner TF, Saari TN 1986 Familial lung disease associated with proliferation and desquamation of type II pneumocytes. Am J Dis Child 140:P262-P266

28. Lankenau HM 1976 A genetic and statistical study of the respiratory distres syndrome. Eur J Pediatr 123:167-177

29. Floros J, DiAngelo S, Koptides M, Karinch AM, Rogan PK, Nielsen H, Spragg RG, Watterberg K, Deiter G 1996 Human SP-A locus: allele frequencies and linkage disequilibrium between the two surfactant protein A genes. Am J Respir Cell Mol Biol 15:489-498

30. McCormick SM, Boggaram V, Mendelson CR 1994 Characterization of mRNA transcripts and organization of human SP-A1 and SP-A2 genes. Am J Physio 266:L354-L366

31. Kala P, Ten Have T, Nielsen H, Dunn M, Floros J 1998 Association of pulmonary surfactant protein A (SP-A) gene and respiratory distress syndrome: interaction with SP-B. Pediatr Res 43:169-177

32. Karinch AM, deMello DE, Floros J 1997 Effect of genotype on the levels of surfactan protein A mRNA and on the SP-A2 splice variants in adult humans. Biochem 321:39-47

33. Ramet M, Haataja R, Marttila R, Floros J, Hallman M 2000 Association between the surfactant protein A (SP-A) gene locus and respiratory-distress syndrome in the Finnish population. Am J Hum Genet 66:1569-1579

34. Korfhagen TR, Bruno MD, Ross GF, Huelsman KM, Ikegami M, Jobe AH, Wert SE, Stripp BR, Morris RE, Glasser SW, Bachurski CJ, Iwamoto HS, Whitsett JA 1996 Altered surfactant function and structure in SP-A gene targeted mice. Proc Natl Acad Sci USA 93:9594-9599

35. Ikegami M, Korfhagen TR, Whitsett JA, Bruno MD, Wert SE, Wada K, Jobe AH 1998 Characteristics of surfactant from SP-A-deficient mice. Am J Physio 275:L247-L254

36. Ikegami M, Korfhagen TR, Bruno MD, Whitsett JA, Jobe AH 1997 Surfactan metabolism in surfactant protein A-deficient mice. Am J Physiol 272:L479-L485

37. Thiel S, Reid K 1989 Structures and functions associated with the group of mammalian lectins containing collagen-like sequences. FEBS Lett 250:78-84

38. Sastry K, Ezekowitz RA 1993 Collectins: pattern recognition molecules involved in first line host defense. Curr Opin Immunol 5:59-66

39. Levine AM, Bruno MD, Huelsman KM, Ross GF, Whitsett JA, Korfhagen TR 1997 Surfactant protein A-deficient mice are susceptible to group B streptococcal infection. J Immunol 158:4336-4340

40. Levine AM, Kurak KE, Bruno MD, Stark JM, Whitsett JA, Korfhagen TR 1998 Surfactant protein-A deficient mice are susceptible to Pseudomonas aeruginosa infection. Am J Respir Cell Mol Biol 19:700-708

41. Levine AM, Gwozdz J, Stark J, Bruno M, Whitsett J, Korfhagen T 1999 Surfactan protein-A enhances respiratory syncytial virus clearance in vivo. J Clin Invest 103:1015-1021

42. Whitsett JA, Nogee LM, Weaver TE, Horowitz AD 1995 Human surfactant protein B: structure, function, regulation, and genetic disease. Physiol Rev 75:749-757

43. Guttentag SH, Beers MF, Bieler BM, Ballard PL 1998 Surfactant protein B processing in human fetal lung. Am J Physiol 275:L559-L566

44. Korimilli A, Gonzales LW, Guttentag SH 2000 Intracellular localization of processing events in human surfactant protein B biosynthesis. J Biol Chem 275:8672-8679

45. Nogee LM, de Mello DE, Dehner LP, Colten HR 1993 Brief report: deficiency o pulmonary surfactant protein $\mathrm{B}$ in congenital alveolar proteinosis. N Engl J Med $328: 406-410$

46. Nogee LM, Garnier G, Dietz HC, Singer L, Murphy AM, deMello DE, Colten HR 1994 A mutation in the surfactant protein B gene responsible for fatal neonatal respiratory disease in multiple kindreds. J Clin Invest 93:1860-1863

47. Beers MF, Hamvas A, Moxley MA, Gonzales LW, Guttentag SH, Soilarin KO, Longmore WJ, Nogee LM, Ballard PL 2000 Pulmonary surfactant metabolism in infants lacking surfactant protein B. Am J Respir Cell Mol Biol 22:380-391

48. Vorbroker DK, Profitt SA, Nogee LM, Whitsett JA 1995 Aberrant processing of surfactant protein C in hereditary SP-B deficiency. Am J Physiol 268:L647-L656

49. Nogee LM 1997 Surfactant protein-B deficiency. Chest 111(6 suppl):129S-135S
50. Hamvas A 1997 Surfactant protein B deficiency: insights into inherited disorders of lung cell metabolism. Curr Probl Pediatr 27:325-345

51. Hamvas A, Cole FS, deMello DE, Moxley M, Whitsett JA, Colten HR, Nogee LM 1994 Surfactant protein B deficiency: antenatal diagnosis and prospective treatment with surfactant replacement. J Pediatr 125:356-361

52. Hamvas A, Nogee LM, Mallory Jr GB, Spray TL, Huddleston CB, August A, Dehner LP, deMello DE, Moxley M, Nelson R, Cole FS, Colten HR 1997 Lung transplantation for treatment of infants with surfactant protein B deficiency. J Pediatr 130:231-239

53. Klein JM, Thompson MW, Snyder JM, George TN, Whitsett JA, Bell EF, McCray Jr PB, Nogee LM 1998 Transient surfactant protein B deficiency in a term infant with severe respiratory failure. J Pediatr 132:244-248

54. Yusen RD, Cohen AH, Hamvas A 1999 Normal lung function in subjects heterozy gous for surfactant protein-B deficiency. Am J Respir Crit Care Med 159:411-414

55. Ballard PL, Nogee LM, Beers MF, Ballard RA, Planer BC, Polk L, deMello DE, Moxley MA, Longmore WJ 1995 Partial deficiency of surfactant protein B in an infant with chronic lung disease. Pediatrics 96:1046-1052

56. Akinbi HT, Breslin JS, Ikegami M, Iwamoto HS, Clark JC, Whitsett JA, Jobe AH, Weaver T 1997 Rescue of SP-B knockout mice with a truncated SP-B proprotein: function of the C-terminal propeptide. J Biol Chem 272:9640-9647

57. Dunbar AE, Wert SE, Hamvas A, White FV, Piedboeuf B, Jobin C, Guttentag S, Nogee LM 2000 Prolonged survival in hereditary surfactant protein B (SP-B) deficiency associated with a novel splicing mutation. Pediatr Res 48:275-282

58. Tokieda K, Ikegami M, Wert SE, Baatz JE, Zou Y, Whitsett JA 1999 Surfactant protein B corrects oxygen-induced pulmonary dysfunction in heterozygous surfactant protein B-deficient mice. Pediatr Res 46:708-714

59. Floros J, Veletza SV, Kotikalapudi P, Krizkova L, Karinch AM, Friedman C, Buchter S, Marks K 1995 Dinucleotide repeats in the human surfactant protein-B gene and respiratory-distress syndrome. Biochem J 305:583-590

60. Kala P, Koptides M, Diangelo S, Hoover RR, Lin Z, Veletza V, Kouretas D, Floros J 1997 Characterization of markers flanking the human SP-B locus. Dis Markers 13:153-167

61. Veletza SV, Rogan PK, TenHave T, Olowe SA, Floros J 1996 Racial differences in allelic distribution at the human pulmonary surfactant protein B gene locus (SP-B). Exp Lung Res 22:489-494

62. Todd S, Naylor SL 1991 Dinucleotide repeat polymorphism in the human surfactantassociated protein 3 gene (SFTP3). Nucleic Acids Res 19:3756 (abstr)

63. Lin Z, deMello DE, Wallot M, Floros J 1998 An SP-B gene mutation responsible for SP-B deficiency in fatal congenital alveolar proteinosis: evidence for a mutation hotspot in exon 4. Mol Gen Metab 64:25-35

64. Cole FS, Hamvas A, Rubinstein P, King E, Trusgnich M, Nogee LM, DeMello DE, Colten HR 2000 Population-based estimates of surfactant protein B deficiency. Pediatrics 105:538-541

65. Nogee LM, Wert SE, Proffit SA, Hull WM, Whitsett JA 2000 Allelic heterogeneity in hereditary surfactant protein B (SP-B) deficiency. Am J Respir Crit Care Med 161:973-981

66. Weaver TE, Whitsett JA 1991 Function and regulation of expression of pulmonary surfactant-associated proteins. Biochem J 273:249-264

67. Johansson J 1998 Structure and properties of surfactant protein C. Biochim Biophys Acta 1408:161-172

68. Beers MR, Lomax CA, Russo SJ 1998 Synthetic processing of surfactant protein C by alveolar epithelial cells: the $\mathrm{COOH}$ terminus of proSP-C is required for posttranslational targeting and proteolysis. J Biol Chem 273:15287-15293

69. Glasser WS, Burhans MS, Korfhagen TR, Bruno MD, Ross GF, Wert SE, Ikegami M, Jobe AH, Whitsett JA 2000 Generation of an SP-C deficient mouse by targeted gene inactivation. Am J Respir Crit Care Med 161:A43(abstr)

70. Nogee LM, Dunbar AE, Wert SE, Askin F, Hamvas A, Whitsett JA 2001 A mutation in the surfactant protein $\mathrm{C}$ (SP-C) gene associated with familial interstitial lung disease. N Engl J Med 344:573-579

71. Eggleton P, Reid KB 1999 Lung surfactant proteins involved in innate immunity Curr Opin Immunol 11:28-33

72. Wright JR 1997 Immunomodulatory functions of surfactant. Physiol Rev 77:931-962

73. Botas C, Poulain R, Akiyama J, Brown C, Allen L, Goerke J, Clements J, Carlson E, Gillespie AM, Epstein C, Hawgood S 1998 Altered surfactant homeostasis and alveolar type II cell morphology in mice lacking surfactant protein D. Proc Natl Acad Sci USA 95:11869-11874

74. Wert SE, Yoshida M, LeVine AM, Ikegami M, Jones T, Ross GF, Fisher JH, Korfhagen TR, Whitsett JA 2000 Increased metalloproteinase activity, oxidant production, and emphysema in surfactant protein D gene-inactivated mice. Proc Natl Acad Sci USA 97:5972-5977

75. Floros J, Hoover RR 1998 Genetics of the hydrophilic surfactant proteins A and D Biochim Biophys Acta 1408:312-322

76. Diangelo S, Lin ZW, Wang GR, Phillips S, Ramet M, Luo JM, Floros J 1999 Novel, non-radioactive, simple and multiplex PCR-cRFLP methods for genotyping human SP-A and SP-D marker alleles. Dis Markers 15:269-281

77. Dranoff G, Crawford AD, Sadelain M, Ream B, Rashid A, Bronson RT, Dickersin GR, Bachurski CJ, Mark EL, Whitsett JA. 1994 Involvement of granulocyte-macrophage colony-stimulating factor in pulmonary homeostasis. Science 264:713-716

78. Dirksen U, Nishinakamura R, Groneck P, Hattenhorst U, Nogee L, Murray R, Burdach S 1997 Human pulmonary alveolar proteinosis associated with a defect in GM-CSF/IL-3/IL-5 receptor common beta chain expression. J Clin Invest 100:22112217

79. Kitamura T, Tanaka N, Watanabe J, Uchida K, Kanegasaki S, Yamada Y, Nakata K 1999 Idiopathic pulmonary alveolar proteinosis as an autoimmune disease with neutralizing antibody against granulocyte/macrophage colony-stimulating factor. J Exp Med 190:875-880 
80. Thomassen MJ, Yi T, Raychaudhuri B, Malur A, Kavuru MS 2000 Pulmonary alveolar proteinosis is a disease of decreased availability of GM-CSF rather than an intrinsic cellular defect. Cell Immunol 95:85-92

81. Reed JA, Ikegami M, Cianciolo ER, Lu W, Cho PS, Hull W, Jobe AH, Whitsett JA 1999 Aerosolized GM-CSF ameliorates pulmonary alveolar proteinosis in GM-CSFdeficient mice. Am J Physiol 276:L556-L563

82. Reed JA, Whitsett JA 1998 Granulocyte-macrophage colony-stimulating factor and pulmonary surfactant homeostasis. Proc Assoc Am Physicians 110:321-332

83. Underhill PA, Jin L, Lin AA, Mehdi SQ, Jenkins T, Vollrath D, Davis RW, Cavalli-Sforza LL, Oefner PJ 1997 Detection of numerous Y chromosome biallelic polymorphisms by denaturing high-performance liquid chromatography. Genet Res 7:996-1005
84. Hacia JG 1999 Resequencing and mutational analysis using oligonucleotide microarrays. Nat Genet 21:42-47

85. Schork NL 1997 Genetics of complex disease-approaches, problems, and solutions. Am J Respir Crit Care Med 156(suppl):S103-S109

86. Wolf U 1995 The genetic contribution to the phenotype. Hum Genet 95:127-148

87. Warden CH, Fisler JS 1997 Integrated methods to solve the biological basis of common diseases. Methods 13:347-357

88. McEwen JE, Reilly PR 1994 Stored Guthrie cards as DNA “banks.” Am J Hum Genet 55:196-200

89. McCabe ERB 1991 Utility of PCR for DNA analysis from dried blood spots on filter paper blotters. PCR Methods Appl 1:99-106 